\title{
Chemical, physical and technological properties of milk as affected by the mycotoxin load of dairy herds
}

\author{
Ludmila Křižová ${ }^{1}$, Oto Hanuš ${ }^{2}$, Marcela Klimešová ${ }^{2}$, Jan Nedělník ${ }^{3}$, Josef Kučera ${ }^{4}$, Petr Roubal ${ }^{2}$, \\ Jaroslav Kopecký ${ }^{2}$, and Radoslava Jedelská ${ }^{2}$ \\ ${ }^{1}$ Department of Animal Nutrition, Faculty of Veterinary Hygiene and Ecology, \\ University of Veterinary and Pharmaceutical Sciences Brno, Brno, 612 42, Czech Republic \\ ${ }^{2}$ Dairy Research Institute, Ltd., Prague, 160 00, Czech Republic \\ ${ }^{3}$ Agricultural Research, Ltd., Troubsko, 664 41, Czech Republic \\ ${ }^{4}$ Department of Animal Breeding, Faculty of Agronomy, Mendel University Brno, \\ Brno, 613 00, Czech Republic \\ Correspondence to: Ludmila Křížová (krizoval@ vfu.cz)
}

Received: 22 January 2016 - Revised: 27 May 2016 - Accepted: 7 June 2016 - Published: 17 June 2016

\begin{abstract}
The aim of the study was to determine the impacts of different levels of mycotoxin load of Czech dairy herds on the larger scale of the milk indicators including milk physical and technological properties. During three subsequent years individual milk samples (IMSs) were collected from four herds of Czech Fleckvieh (C) and from four herds of Holstein cows (H). The IMSs were collected regularly twice in summer and twice in winter, resulting in a total of 936 IMSs. The feeding rations consisted mainly of conserved roughage and supplemental mixtures according to milk yield and standard demands. Samples of feedstuffs were collected at the same time as IMSs and were analysed for content of deoxynivalenol (DON), fumonisins (FUM), zearalenone (ZEA), aflatoxin (AFL), and T-2 toxin using enzyme-linked immunosorbent assay (ELISA) methods. Based on the mycotoxin load, herds were divided into three groups - Load 1 (negligible, $n=36$ ), Load 2 (low, $n=192$ ), and Load 3 (medium, $n=708$ ). All feedstuff samples were positive for at least one mycotoxin. The most frequently occurring mycotoxins were FUM, DON, and ZEA. Relatively high incidence of AFL ( $56 \%$ positive samples) was observed. The following milk indicators were influenced by the mycotoxin load of herds: fat, acetone (Ac), $\log \mathrm{Ac}, \mathrm{pH}$, electric conductivity, alcohol stability, curds quality, curd firmness, whey volume, whey protein, non-protein nitrogen (NPN), urea N in NPN, fat / crude protein ratio, and casein numbers on crude and true protein basis, respectively $(P<0.05)$. The overall level of mycotoxin load was relatively low, with no clear effect on milk characteristics.
\end{abstract}

\section{Introduction}

Livestock production plays a significant role in production of a high-quality food. The quality of products of animal origin depends largely on the safety and quality of feedstuffs ingested by animals. Within the central European environment, breeding of high-yielding dairy cows relies mainly on two feeding strategies: (1) whole-year indoor feeding (conserved forages + compound feed) and (2) winter indoor feeding based on conserved forages followed by seasonal access to pasture, both supplemented with the compound feeds. These feedstuffs are often contaminated by mycotoxins. Although research on mycotoxin occurrence in animal feedstuff has been primarily focused on grain and cereal feeding components (Zinedine et al., 2007), recent studies have documented a high occurrence of mycotoxins in various types of forages, mainly conserved ones (Driehuis et al., 2008; Zachariášová et al., 2014), representing a significantly different spectrum of toxins than in cereals. Thus, dairy cows can be exposed to a broad range of mycotoxins that occur in compound feeds, conserved forages, and pasture. Although concentration of mycotoxins in forage feedstuffs is usually under the legislative limits (see Commission of the European Communities, 2006/576/EC, 
Table 1. Basic information about dairy herds and their environment and feeding.

\begin{tabular}{|c|c|c|c|c|c|c|c|}
\hline Herd no. & Breed & $n$ & $\begin{array}{r}\text { Milk yield/ } \\
\text { lactation }\end{array}$ & $\begin{array}{r}\text { Altitude } \\
(\mathrm{m})\end{array}$ & $\begin{array}{r}\text { Mean annual } \\
\text { temperature }\left({ }^{\circ} \mathrm{C}\right)\end{array}$ & $\begin{array}{r}\text { Annual } \\
\text { rainfall }(\mathrm{mm})\end{array}$ & Feeding \\
\hline 1 & $\mathrm{C}$ & 120 & 6553 & 225 & 9.7 & 537 & $\begin{array}{l}\text { lucerne silage }+ \text { maize silage, } \\
\text { the whole year }\end{array}$ \\
\hline 2 & $\mathrm{C}$ & 118 & 5695 & 570 & 6.7 & 812 & $\begin{array}{l}\text { clover-grass/grass silage }+ \text { maize silage } \\
\text { the whole year }\end{array}$ \\
\hline 3 & $\mathrm{C}$ & 120 & 5580 & 605 & 7.1 & 663 & $\begin{array}{l}\text { clover-grass silage }+ \text { maize silage, } \\
\text { the whole year }\end{array}$ \\
\hline 4 & $\mathrm{C}$ & 120 & 6450 & 600 & 7.3 & 866 & $\begin{array}{l}\text { grass silage }+ \text { GPS from cereals or maize } \\
\text { silage or sugar beet chips in winter and } \\
\text { a similar mixture with grass pasture in } \\
\text { summer }\end{array}$ \\
\hline 5 & $\mathrm{H}$ & 120 & 6988 & 215 & 10.2 & 492 & $\begin{array}{l}\text { lucerne silage }+ \text { maize silage, } \\
\text { the whole year }\end{array}$ \\
\hline 6 & $\mathrm{H}$ & 122 & 7273 & 570 & 6.7 & 812 & $\begin{array}{l}\text { clover-grass/grass silage }+ \text { maize silage, } \\
\text { the whole year }\end{array}$ \\
\hline 7 & $\mathrm{H}$ & 96 & 9929 & 550 & 7.2 & 763 & $\begin{array}{l}\text { clover-grass/grass silage }+ \text { maize silage, } \\
\text { the whole year }\end{array}$ \\
\hline 8 & $\mathrm{H}$ & 120 & 7391 & 300 & 9.3 & 686 & $\begin{array}{l}\text { clover-grass silage }+ \text { maize silage, } \\
\text { the whole year }\end{array}$ \\
\hline
\end{tabular}

$n=$ number of cows sampled per herd; C: Czech Fleckvieh; H: Holstein; GPS: silage from whole maize plant in vax maturity.

2006), the contribution of forage to the total dietary intake of mycotoxins may be significant (Driehuis et al., 2008) because forages are the fundamental dry-matter component of dairy diets. Thus, subclinical exposure of dairy cows to mycotoxins may be much more frequent, resulting in nonspecific symptoms and affecting animal productivity and health. Furthermore, co-occurrence of several mycotoxins with different modes of action should be also taken into account because of their potential additive and/or synergistic effects. For example, while a high incidence of co-occurrence of deoxynivalenol (DON) and zearalenone (ZEA) in maize silage is observed globally, the incidence of other mycotoxins differs widely depending on environmental conditions (Driehuis et al., 2008; Zachariášová et al., 2014). Although DON and ZEA, with their very low carry-over rates from feed to milk, are not of significant concern with respect to the safety of dairy products (Coffey et al., 2009), they are of concern to the dairy sector primarily because of their potential adverse effects on cows' health and performance (Galtier, 1998).

Studies focused on the effect of mycotoxins on animal health and performance are commonly performed under well-defined conditions with one or two mycotoxins. However, experimental conditions differ from farm conditions, where animals may be exposed to various levels of mycotoxin "cocktail". Furthermore, studies focused on the impact of mycotoxins on a complex of physical, chemical, and technological properties of raw bovine milk are lacking. Thus, the aim of the study was to determine the impacts of different levels of mycotoxin load of Czech dairy herds on the larger scale of milk indicators, including those characterizing milk physical and technological properties.

\section{Material and methods}

During three subsequent experimental years, individual milk samples (IMSs) were collected from four herds of Czech Fleckvieh (C, herds 1-4) and from four herds of Holstein cows (H, herds 5-8). Main characteristics of herds, including details about their environmental characteristics and feeding, are given in Table 1. Within herds, higher yielding animals were randomly selected with regard to the number and stage of lactation corresponding to a real profile of herd. The IMSs were collected during summer (August and September) and winter (February and March) season representing the situation in contrast parts of the year in the Czech Republic environment, it is the effect of season. One herd was milked three times a day, while the others were milked twice a day. Milk yield was measured using Tru-Test flow milk meters or by the electronic milk flow meters. IMSs were analysed as preservation-free or preserved (with Bronopol $0.04 \%$ ) after cooled transport $\left(<10^{\circ} \mathrm{C}\right)$. All samples were transported to the accredited National Reference Laboratory for raw milk analysis (according to ČSN EN ISO/IEC 17025, 2005) in the Research Institute for Cattle Breeding, Ltd., in Rapotín (Czech Republic). 


\subsection{Analyses and abbreviations of determined milk indicators}

The analytical procedures were described in the previous studies of Hanuš et al. (2007) or Janů et al. (2007). Briefly, composition and physical-chemical and technological properties of milk were carried out according to the following methods:

- Fat, lactose and solids-not-fat were measured using MilkoScan 133B (Foss Electric, Denmark).

- Crude protein (CP), true protein (TP), and casein (Cas) were determined by reference Kjeldahl's method using the instrument line Tecator with a Kjeltec 2200 autodistillation unit (Foss-Tecator AB, Sweden) according to ČSN 570530 (1973).

- Somatic cell count (SCC) was determined using Fossomatic 90 instrument (Foss Electric, Denmark) according to ČSN EN ISO 13366-3 (1998).

- Urea was determined using an Ureakvant apparatus (Agroslužby Olomouc, Czech Republic) based on specific enzymatic and conductometric method.

- Acetone (Ac) was determined by spectrophotometry at $485 \mathrm{~nm}$ wavelength using a Spekol 11 instrument (Carl Zeiss Jena, Germany).

- Electric conductivity was measured using an $\mathrm{OK}$ $102 / 1$ (Radelkis, Hungary) conductometer at $20^{\circ} \mathrm{C}$ (in $\mathrm{mS} \mathrm{cm}{ }^{-1}$ ).

- Active acidity $(\mathrm{pH})$ was measured using a CyberScan $510 \mathrm{pH}$ meter (Eutech Instruments) at $20^{\circ} \mathrm{C}$.

- Titration acidity was measured according to the standard ČSN 570530 (1973).

- Milk alcohol stability was determined with the help of milk titration $(5 \mathrm{~mL})$ by $96 \%$ ethanol for the creation of the first visible milk protein precipitated flakes.

- Rennet coagulation time - time for enzymatic coagulation from the addition of rennilase (microbial enzyme) to milk to the beginning of coagulation (s).

- Curd quality - subjective estimation of curd cake quality determined by inspection and touch from first (excellent) to fourth (poor) class.

- Cheese curd firmness - depth of penetration of the corpuscle falling into curd cake in a standard way ( $\mathrm{mm}$; the higher the firmness, the fewer millimetres).

- Whey volume - obtained during the process of enzymatic cheese making from curd cake for $60 \mathrm{~min}$ $(\mathrm{mL})$.
Table 2. Characteristics of classes of individual mycotoxins based on their content (ppb) in individual feedstuff samples.

\begin{tabular}{lcccc}
\hline & \multicolumn{4}{c}{ Class } \\
\cline { 2 - 5 } & 1 & 2 & 3 & 4 \\
\hline Deoxynivalenol (DON) & 0 & Under 500 & $500-1500$ & Above 1500 \\
Fumonisins (FUM) & 0 & Under 500 & $500-1500$ & Above 1500 \\
Zearalenone (ZEA) & 0 & Under 500 & $500-1500$ & Above 1500 \\
Aflatoxins (AFL) & 0 & Under 1 & $1-3$ & Above 3 \\
T-2 toxin (T2) & 0 & Under 50 & $50-150$ & Above 150 \\
\hline
\end{tabular}

The following milk indicators were calculated: whey protein, non-protein nitrogen (NPN), fat to crude protein ratio (fat / CP), urea N in NPN ratio, casein number on crude protein basis (Cas-CP), and casein number on true protein basis (Cas-TP).

The feeding rations consisted of roughage (see Table 1) and supplements of concentrate mixture according to milk yield and standard demands. Samples of feedstuffs were collected at the same time as the IMSs. Commercially available quantitative enzyme-linked immunosorbent assay (ELISA) kits (Veratox, Neogen Corp., Lansing, MI, USA) were used for measuring the presence of the mycotoxins deoxynivalenol (DON), fumonisins (FUM), zearalenone (ZEA), aflatoxin (AFL), and T-2 toxin according to the manufacturer's instructions. Based on the obtained results for each analysed feedstuff, a class of mycotoxin load was calculated as a mean from classes assigned to individual mycotoxins (see Table 2). Four classes were created under the correlation of mycotoxin amount with recommendation limits. Class 1 was represented by samples with no mycotoxins, in class 2 there were samples under the concentration limit, and in class 4 there were samples with more than 3 times the concentration limit. Finally, the load of herds was classified as negligible (Load 1: mean class 1), low (Load 2: mean class 2), and medium (Load 3: mean class 3).

\subsection{Statistical analysis}

Basic statistical characteristics were calculated: arithmetical mean $(x)$, geometrical mean $\left(x_{\mathrm{g}}\right)$, standard deviation (SD), and $t$ values for significance assessing of the differences (MS Excel - Microsoft, Redmond, Washington, USA). Some values (acetone and somatic cell count) were logtransformed (Hanuš et al., 2007; Janů et al., 2007) as the data were not normally distributed and also for possibility to use the geometrical means.

The GLM procedure of the SAS v. 9 program package was used for the calculation. Multifactor analysis of variance with fixed effects as breed, season, and feeding system was used for statistical evaluation of dataset, according to the following model:

$y_{i-q}=\mu+h_{i}+y_{j}+s_{k}+l_{l}+b_{m}+d_{n}+m_{o}+c_{p}+f_{q}+e_{i-q}$, 
Table 3. Occurrence of mycotoxins in feedstuffs and their assignment into classes characterizing mycotoxin load of herds.

\begin{tabular}{lrrrrr}
\hline No. of total/positive samples & $\begin{array}{r}\text { DON } \\
97 / 71\end{array}$ & $\begin{array}{r}\text { FUM } \\
97 / 80\end{array}$ & $\begin{array}{r}\text { ZEA } \\
97 / 66\end{array}$ & $\begin{array}{r}\text { AFL } \\
97 / 54\end{array}$ & $\begin{array}{r}\text { T2 } \\
97 / 35\end{array}$ \\
\hline Class 1 - no. of samples & 7 & 16 & 9 & 11 & 5 \\
Class 2 - no. of samples & 13 & 27 & 22 & 18 & - \\
Class 3 - no. of samples & 23 & 28 & 22 & 13 & 8 \\
Class 4 - no. of samples & 28 & 9 & 13 & 12 & 22 \\
Mean class & 3.0 & 2.4 & 2.6 & 2.5 & 3.3 \\
\hline
\end{tabular}

DON: deoxynivalenol; FUM: fumonisins; ZEA: zearalenone; AFL: aflatoxins; T2: T-2 toxin.

where $y_{i-q}$ is an independent variable (investigated milk indicator), $\mu$ is the general mean, $h_{i}$ is the effect of herd $(i=8), y_{j}$ is the effect of year $(j=3), s_{k}$ is the effect of season $(k=2), l_{l}$ is the effect of the number of lactations $(l=10), b_{m}$ is the effect of breed $(m=2), d_{n}$ is the effect of the stage of lactation ( $n=3,<100,100-200,>200$ DIM), $m_{o}$ is the effect of mycotoxin load $(o=3), c_{p}$ is the effect of feeding class ( $p=9$, based on energy: CP ratio), $f_{q}$ is the effect of the type of feeding ( $q=4$, based on the proportion and type of roughage in the diet), and $e_{i-q}$ is the random effect.

\section{Results}

\subsection{Mycotoxin load of herds}

In the present experiment cows were fed mainly on various types of silage (maize, lucerne, clover/grass, cereals) as documented in Table 1. Although all samples were positive for at least one mycotoxin, the overall level of mycotoxin contamination of feedstuffs of studied herds was relatively low. The most frequently occurring mycotoxins were FUM, DON, and ZEA, with 82,73 , and $68 \%$ of positive samples, respectively (see Table 3 ). Relatively high incidence of AFL (56\% positive samples) was also registered in our study. Co-occurrence of two mycotoxins was observed in $98 \%$ of samples; $80 \%$ of samples contained three or more mycotoxins (data not shown). Only 36 IMSs were included in Load 1, with negligible mycotoxin load, while the majority of IMSs belonged to the low (Load 2, 192 IMSs) and medium (Load 3, 708 IMSs) levels of mycotoxin contamination, suggesting that not only occurrence of mycotoxins in silage but also a risk of subclinical exposure of dairy cows to mycotoxins may be much more frequent than expected.

\subsection{Effect of mycotoxin load on basic milk indicators}

Results of our 3-year study on a total of 936 IMSs that were analysed for a wide scale of chemical, physical, and technological characteristics depending on the mycotoxin load of herds are given in Table 4. The concentration of milk fat differed significantly among groups $(P<0.001)$, while content of lactose, crude, and true protein and casein was not affected by the mycotoxin load $(P>0.05)$. There was a tendency found in solids-non-fat $(P=0.0877)$.

\subsection{Effect of mycotoxin load on health status indicators}

The SCC tended to differ among groups with the numerically highest value in Load $3\left(237\right.$ th $\left.\mathrm{mL}^{-1}\right)$ and the lowest value in Load 1 (104 th $\left.\mathrm{mL}^{-1}, P=0.0918\right)$. However, logtransformed SCC did not differ significantly $(P>0.05)$. Content of urea was the lowest in Load 1 and the highest in Load 2. Although the numerical differences among groups were relatively high, urea was not significantly influenced by the mycotoxin load of herds; however, a strong tendency was observed $(P=0.056)$. Concentrations of Ac, as well as $\log$ Ac, were significantly different among groups $(P<0.01$ and $P<0.001$, respectively), with highest values found in Load 1 , where the lowest milk yield was also observed. Fat / CP differed significantly between Load 1 and Loads 2 and 3 $(P<0.001)$; however, the difference was quite low.

\subsection{Effect of mycotoxin load on physical indicators}

Electric conductivity differed among groups $(P<0.001)$, with the highest value in Load 1 and the lowest in Load 2. The active acidity $(\mathrm{pH})$ was the lowest in Load 1 (6.708) and the highest in Load 3 (6.731, $P<0.01)$.

\subsection{Effect of mycotoxin load on technological indicators}

Titration acidity was not influenced by the mycotoxin load of herds $(P>0.05)$. Alcohol stability as an indirect marker of milk protein thermostability differed significantly $(P<$ 0.001). Although rennet coagulation time in our study was not influenced by the mycotoxin load $(P>0.05)$, the class of curd quality differed among groups $(P<0.001)$, with the lowest value in Load 2 (2.26), while values in Load 1 and 3 were almost identical (2.69). Cheese curd firmness decreased from $17.61 \mathrm{~mm}$ in Load 1 to $16.36 \mathrm{~mm}$ in $\operatorname{Load} 3(P<$ $0.001)$. Content of crude protein, casein, and true protein were not affected by the mycotoxin load, while content of whey protein, non-protein nitrogen, and whey volume differed significantly among groups $(P<0.05)$. Similarly, there were differences in the casein numbers (on the basis of CP and TP) among groups depending on the mycotoxin load of herds $(P<0.001)$.

\section{Discussion}

As has already been mentioned, contamination of feedstuffs by mycotoxins is a serious problem. The contribution of forages to the total dietary intake of mycotoxins may be significant as forages are the main dry-matter component of the dairy diet. According to a survey conducted by Driehuis et al. (2008), silage and compound feeds were the main components of the dairy diet, representing on average 67 and 
Table 4. Chemical, physical, and technological characteristics of milk depending on the mycotoxin load of dairy herds.

\begin{tabular}{|c|c|c|c|c|c|c|c|c|c|c|c|}
\hline & & \multicolumn{10}{|c|}{ Mycotoxin load of dairy herds } \\
\hline & & \multicolumn{3}{|c|}{ Load $1(n=36)$} & \multicolumn{3}{|c|}{ Load $2(n=192)$} & \multicolumn{3}{|c|}{ Load $3(n=708)$} & \multirow[t]{2}{*}{$P$} \\
\hline & & $x$ & $x_{\mathrm{g}}$ & SD & $x$ & $x_{\mathrm{g}}$ & SD & $x$ & $x_{\mathrm{g}}$ & SD & \\
\hline No. of lactations & & 2.5 & & 1.21 & 2.4 & & 1.38 & 2.5 & & 1.42 & \\
\hline Days in milk & & 143 & & 74.68 & 145 & & 66.01 & 148 & & 83.61 & \\
\hline Milk yield & $\mathrm{kg}$ & 24.8 & & 5.00 & 27.1 & & 7.89 & 26.5 & & 8.14 & \\
\hline Fat & $\mathrm{g} 100 \mathrm{~g}^{-1}$ & 3.62 & & 0.94 & 4.03 & & 0.80 & 3.94 & & 0.92 & $<0.001$ \\
\hline Lactose & $\mathrm{g} 100 \mathrm{~g}^{-1}$ & 4.97 & & 0.22 & 4.97 & & 0.18 & 4.97 & & 0.22 & 0.587 \\
\hline Solids-non-fat & $\mathrm{g} 100 \mathrm{~g}^{-1}$ & 8.47 & & 0.36 & 8.88 & & 0.35 & 8.82 & & 0.37 & 0.088 \\
\hline Crude protein $(\mathrm{CP})$ & ${\mathrm{g} 100 \mathrm{~g}^{-1}}$ & 3.00 & & 0.27 & 3.41 & & 0.34 & 3.31 & & 0.34 & 0.243 \\
\hline True protein (TP) & $\mathrm{g} 100 \mathrm{~g}^{-1}$ & 2.87 & & 0.25 & 3.23 & & 0.31 & 3.13 & & 0.32 & 0.678 \\
\hline Casein (Cas) & $\mathrm{g} 100 \mathrm{~g}^{-1}$ & 2.37 & & 0.21 & 2.72 & & 0.28 & 2.63 & & 0.30 & 0.206 \\
\hline Somatic cell count & th $\mathrm{mL}^{-1}$ & 104 & & 103.58 & 164 & & 338.28 & 237 & & 578.10 & 0.092 \\
\hline Log somatic cell count & & 1.84886 & 70.610 & 0.38 & 1.82059 & 66.159 & 0.53 & 1.89772 & 79.016 & 0.57 & 0.134 \\
\hline Urea & $\operatorname{mgdL}{ }^{-1}$ & 12.35 & & 3.70 & 31.43 & & 15.70 & 25.45 & & 10.13 & 0.056 \\
\hline Acetone & $\mathrm{mg} \mathrm{L}^{-1}$ & 4.97 & & 6.05 & 2.76 & & 3.13 & 2.78 & & 3.96 & 0.002 \\
\hline Log acetone & & 0.338 & 2.177 & 0.69 & 0.301 & 1.999 & 0.39 & 0.23 & 1.704 & 0.46 & $<0.001$ \\
\hline Fat/crude protein & & 1.21 & & 0.35 & 1.18 & & 0.24 & 1.19 & & 0.27 & $<0.001$ \\
\hline $\mathrm{pH}$ & & 6.708 & & 0.07 & 6.727 & & 0.08 & 6.731 & & 0.14 & 0.002 \\
\hline Electric conductivity & $\mathrm{mS} \mathrm{cm}^{-1}$ & 4.46 & & 0.44 & 4.25 & & 0.40 & 4.34 & & 0.53 & $<0.001$ \\
\hline Alcohol stability & $\mathrm{mL}$ & 1.05 & & 0.34 & 1.36 & & 0.69 & 1.52 & & 1.01 & $<0.001$ \\
\hline Titration acidity & ${ }^{\circ} \mathrm{SH}$ & 7.26 & & 0.73 & 7.73 & & 0.99 & 7.36 & & 0.95 & 0.128 \\
\hline Rennet coagulation time & $\mathrm{s}$ & 89.44 & & 37.65 & 105.37 & & 40.50 & 116.32 & & 57.26 & 0.266 \\
\hline Curd quality & class & 2.69 & & 1.02 & 2.25 & & 0.99 & 2.69 & & 0.95 & $<0.001$ \\
\hline Cheese curd firmness & $\mathrm{cm}$ & 17.61 & & 2.72 & 16.60 & & 2.78 & 16.36 & & 3.37 & $<0.001$ \\
\hline Whey volume & $\mathrm{mL}$ & 37.28 & & 2.77 & 35.16 & & 2.83 & 35.12 & & 3.54 & 0.021 \\
\hline Whey protein & $\mathrm{g} 100 \mathrm{~g}^{-1}$ & 0.50 & & 0.10 & 0.51 & & 0.10 & 0.50 & & 0.09 & 0.009 \\
\hline Non-protein nitrogen (NPN) & $\mathrm{g} 100 \mathrm{~g}^{-1}$ & 0.12 & & 0.06 & 0.18 & & 0.07 & 0.18 & & 0.06 & $<0.001$ \\
\hline Urea $\mathrm{N}$ in NPN & $\%$ & 33.99 & & 16.05 & 50.58 & & 18.45 & 42.34 & & 16.16 & $<0.001$ \\
\hline Casein number on $\mathrm{CP}$ basis & $\%$ & 79.18 & & 3.16 & 79.82 & & 3.12 & 79.25 & & 2.92 & $<0.001$ \\
\hline Casein number on TP basis & $\%$ & 82.57 & & 2.89 & 84.33 & & 2.71 & 83.92 & & 2.69 & 0.001 \\
\hline
\end{tabular}

$n$ : number of observations; $x$ : arithmetic mean; $x_{\mathrm{g}}$ : geometric mean, $\mathrm{SD}$ : standard deviation.

$23 \%$ of the dry-matter intake, respectively. Furthermore, in comparison to compound feed the contribution of silage to total intake of DON and ZEA was 3.5 and 2.9 times greater, respectively.

Throughout the study a total of 97 samples of forages were analysed for the content of DON, FUM, ZEA, AFL, and $\mathrm{T}-2$ toxin, which are thought to be the most important mycotoxins from the view of animal health and safety of products of animal origin (Binder, 2007). The spectrum and frequency of occurrence of studied mycotoxins is in agreement with most studies focused on the incidence of mentioned mycotoxins in silage (Driehuis et al., 2008; Zachariášová et al., 2014). Although maize contamination with AFL is usually associated with tropical or subtropical regions but not, in general, with central European countries (e.g. Driehuis et al., 2008; Zachariášová et al., 2014), occurrence of AFL was documented in France (Garon et al., 2006) or Spain (Hernández-Martínez and Navarro-Blasco, 2015) following high temperatures and drought. AFL in our study occurred only in all samples collected in the second year of study and in summer samples collected in the third year (data not shown). These findings indicate that AFL occurrence in silage is associated mainly with environmental conditions of silage crop growth, suggesting that contamination of European agricultural products with aflatoxins cannot be excluded. Co-occurrence of mycotoxins (mainly DON and ZEA) is often reported in the literature (Driehuis et al., 2008; Zachariášová et al., 2014). Similar findings were also found in our study.

\subsection{General description of dataset}

As well documented in the available literature, animal feeding trials are commonly performed under well-defined conditions with one (DON - e.g. Erickson et al., 2011; ZEA - e.g. Zinedine et al., 2007; AFL - e.g. Xiong et al., 2015; T-2 toxin - e.g. Yoshizawa et al., 1981) or two mycotoxins (DON + ZEA - e.g. Winkler et al., 2014; Korosteleva et al., 2007). However, experimental conditions differ from farm conditions where animals may be exposed to a mycotoxin "cocktail" as documented in recent studies describing natural multi-mycotoxin contamination of feedstuffs (Hofstetter and 
Rodrigues, 2009; Kiyothong et al., 2012; Zachariášová et al., 2014). Studies focused on the impact of multi-mycotoxin load on animal performance are scarce and they are usually limited in duration and focused on the counteracting effect of various types of mycotoxin sequestering agents (MSAs).

In general, values of milk indicators determined in our study are in accordance with those characterising ordinary population of dairy cows bred in the Czech Republic environment (e.g. Hanuš et al., 2007; Janů et al., 2007) without differences apparent at first glance that could have been caused by the exposure of cows to various levels of dietary mycotoxins.

\subsection{Effect of mycotoxin load on basic milk indicators}

Our findings concerning basic milk indicators are in accordance with those reported in the literature. Charmley et al. (1993) described quadratic response in milk fat depending on increasing levels of DON in the diet, with no effect of DON on other milk components. According to Korosteleva et al. (2007) milk composition was not affected by a diet containing DON. Similar findings were reported for DON + ZEA (Winkler et al., 2014) or AFL (Xiong et al., 2015). Kiyothong et al. (2012) did not find significant differences in fat, lactose, and solids-non-fat after supplementation of MSAs to multi-mycotoxin (DON, FB1, ZEA, OTA, AFL, and T-2 toxin) contaminated diet, but they reported a positive influence of MSAs on milk protein concentration $(P<0.05)$ and also noted that milk fat percentage tended to be higher for MSA-supplemented than for non-supplemented cows. Similarly, Hofstetter and Rodrigues (2009) found no differences in milk fat, lactose, solids-not-fat, and total solids after multi-mycotoxin exposure with similar tendency in milk fat percentage.

\subsection{Effect of mycotoxin load on health status indicators}

SCC is a well-known indicator of mammary gland health in lactating mammals and is also used as a marker of milk quality. Increased SCC is generally accepted to be the most significant indication of the onset of subclinical mastitis in dairy cows. The immune system is a target of several important mycotoxins such as T-2, DON, and AFL that may affect the metabolic variables and immunity in dairy cows (Bondy and Pestka, 2000). The SCC in our study tended to differ among groups with the numerically highest value in Load 3 and the lowest value in Load $1(P=0.0918)$. This result could indicate the influence of higher mycotoxin load to excite the immune system of cows in the form of increased SCC as a defense against mastitis. Although there is no comparable study evaluating the effect of load of mycotoxin "cocktail" on SCC, changes in SCC after mycotoxins exposure, either significant or numerical, are often reported in the literature. For example, Applebaum et al. (1982) described a slight increase in numerical values of SCC in cows receiving $13 \mathrm{mg}$ of pure AFL. Takagi et al. (2011) observed a relationship between urinary ZEA concentrations as a marker of ZEA exposure and milk SCC, where a decrease in urinary ZEA concentrations accompanied changes in milk SCC; however, in their study, no intake of ZEA was measured. On the other hand, in a subsequent study, Takagi et al. (2013) did not observe significant correlations between an individual cow's urinary ZEA concentrations and SCC. Similarly, SCC was not affected by a diet containing DON (Korosteleva et al., 2007) or AFL (Xiong et al., 2015). There are some studies focused on the effect of various types of MSAs on SCC assuming that MSA supplementation can ameliorate the adverse effects of mycotoxins on animal immunity system. However, results are not consistent. Recently, Hofstetter and Rodrigues (2009) or Kiyothong et al. (2012) found significantly lower SCC $(P<0.05)$ in cows supplemented with MSAs compared with non-supplemented cows and SCC decreased linearly with the increasing level of supplementation. Similarly, Takagi et al. (2011) found significant changes in SCC after MSA supplementation. On the other hand, Korosteleva et al. (2007) did not find a positive effect of MSAs supplemented to a diet containing $3.6 \mathrm{mg} \mathrm{kg}^{-1}$ of DON on SCC.

Milk urea can be used as an indicator of the nutritional status of the dairy herd mostly with negative relation to reproductive performance and longevity. In our study, a strong tendency for differences in milk urea was observed $(P=0.056)$. There is no comparable study except for that Kiyothong et al. (2012), who did not find differences in milk urea in cows fed diets containing DON, FB1, ZEA, OTA, AFL, and T-2 with or without MSA supplement. On the other hand, lower urea values were reported with lower milk yield between breeds in many studies (e.g. Hanuš et al., 2007; Janů et al., 2007). A similar relationship was also observed in our study. Thus, it is likely that differences among groups in milk urea were caused rather by differences in milk yield than by mycotoxin load itself.

Milk acetone (Ac) is an indicator of cow energy metabolism. Significant differences in Ac concentration $(P<0.01)$ determined in our study are in accordance with Janů et al. (2007) but in disagreement with Hanuš et al. (2007). However, the opposite results (for the two breeds, Holstein and Czech Fleckvieh: Janů et al., 2007, Hanuš et al., 2007, respectively) could be caused by breed (specific physiology of lactation) in relation to the milk yield with low incidence of subclinical ketosis in the both above-mentioned studies.

The fat / CP ratio is considered a good indicator of energy metabolism of dairy cows and also an indicator of cheesemaking properties of milk. In our study, fat / CP differed significantly between Load 1 and Loads 2 and $3(P<$ 0.001). According to Hanuš et al. (2004), the fat / CP ratio is positively well correlated with milk Ac. Similar findings were also observed in our study. 


\subsection{Effect of mycotoxin load on physical indicators}

Electric conductivity as a possible indicator of udder health differed significantly among groups $(P<0.001)$. According to Hanuš et al. (2007) and Janů et al. (2007), lower values of milk electric conductivity are observed in milk with lower SCC. This was not confirmed in our study. As proved by Nájera et al. (2003) changes in milk pH affect the rennet coagulation time. Although significant $(P<0.01)$, differences in $\mathrm{pH}$ in our study were too small to influence the rennet coagulation time.

\subsection{Effect of mycotoxin load on technological indicators}

There are no comparable data in the available literature concerning the effect of mycotoxin load on cheese-making properties of milk such as rennet coagulation time, curd quality, curd firmness, and volume of whey separated out during the process of enzymatic coagulation of milk. Furthermore, the technological quality of milk is influenced not only by content of basic components (fat, protein, lactose, and solids-non-fat) but also by parameters such as active acidity $(\mathrm{pH})$ or titration acidity (Janů et al., 2007; Hanuš et al., 2007). Changes in $\mathrm{pH}$ were discussed above and titration acidity was not influenced by the mycotoxin load of herds $(P>0.05)$. The higher value of alcohol stability that was observed in Load 2 and Load $3(P<0.001)$ was accompanied by higher milk yields and a lower value of curd firmness. These findings are in agreement with Hanuš et al. (2007).

Rennet coagulation time significantly influences the process of cheese making as well as the yield and quality of formed cheese, and it is an important parameter used in the evaluation of milk suitability for processing and cheese making (e.g. Cassandro et al., 2008). Results concerning the cheese-making indicators such as rennet coagulation time, cheese curd firmness, class of curd quality, whey volume, or casein numbers did not show a clear tendency explaining the possible effect of mycotoxins on cheesemaking properties of milk, partly because of relatively low exposure to mycotoxins and partly because of differences in factors that are involved in the cheese-making ability of milk such as titratable acidity, SCC, protein, and casein contents and calcium and phosphorus concentrations (e.g. Jõudu et al., 2008). Further studies are needed to clarify a possible role of dietary mycotoxins on physical and technological properties of milk.

In conclusion, results of our study concerning the mycotoxin contamination of silage confirmed current knowledge on their occurrence and co-occurrence in these kinds of feedstuffs. Furthermore, the presence of aflatoxins in silage in the central European conditions should not be ignored.

The content of basic milk components except for fat was not influenced by the mycotoxin load of herds. From the physical and technological characteristics, acetone, $\mathrm{pH}$, electric conductivity, alcohol stability, curds quality, curd firmness, whey volume, whey protein, non-protein nitrogen (NPN), urea N in NPN, fat / crude protein ratio, and casein numbers on crude and true protein basis were significantly affected by the mycotoxin load of herds. However, these results did not show a clear tendency explaining the possible effect of mycotoxins on cheese-making properties of milk, partly because of relatively low exposure to mycotoxins and partly because of the number of interference interactions among milk indicators.

Acknowledgements. This study was supported by project MZe NAZV KUS QJ1230044 and by the institutional support by decisions MZe RO1415, MZe RO1714 and grant no. MSMT 6215712402 .

Edited by: M. Mielenz

Reviewed by: E. Samková and one anonymous referee

\section{References}

Applebaum, R. S., Brackett, R. E., Wiseman, D. W., and March, E. H.: Responses of dairy cows to dietary aflatoxin: Feed intake and yields, toxin content, and quality of milk of cows treated with pure and impure aflatoxin, J. Dairy Sci., 65, 1503-1508, 1982.

Binder, E. M.: Managing the risk of mycotoxins in modern feed production, Anim. Feed Sci., 133, 149-166, doi:10.1016/j.anifeedsci.2006.08.008, 2007.

Bondy, G. S. and Pestka, J. J.: Immunomodulation by fungal toxins, J. Toxicol. Environ. Health B, 3, 109-143, doi:10.1080/109374000281113, 2000.

Cassandro, M., Comin, A., Ojala, M., Zotto, R. D., de Marchi, M., Gallo, L., Carnier, P., and Bittante G.: Genetic parameters of milk coagulation properties and their relationships with milk yield and quality traits in Italian Holstein cows, J. Dairy Sci., 91, 371-376, doi:10.3168/jds.2007-0308, 2008.

Coffey, R., Cummins, E., and Ward, S.: Exposure assessment of mycotoxins in dairy milk, Food Control, 20, 239-249, doi:10.1016/j.foodcont.2008.05.011, 2009.

Commission of the European Communities: Commission Recommendation of 17 August 2006 on the presence of deoxynivalenol, zearalenone, ochratoxin A, T-2 and HT-2 and fumonisins in products intended for animal feeding, Official Journal of the European, 2006/576/ES, 2006.

ČSN 57 0530: Methods for testing of milk and milk products, Vydavatelství úřadu pro normalizaci a měření, Praha, 108 pp., 1973 (in Czech).

ČSN EN ISO 13366-3: Milk - enumeration of somatic cells - Part 3: Fluoro-opto-electronic method, Český Normalizační Institut, Praha, 16 pp., 1998 (in Czech).

ČSN EN ISO/IEC 17025: Conformity assessment - general requirements for the competence of testing and calibration laboratories, Český Normalizační Institut, Praha, 48 pp., 2005 (in Czech).

Driehuis, F., Spanjer, M. C., Scholten, J. M., and Te Giffel, M. C.: Occurrence of mycotoxins in feedstuffs of dairy cows and 
estimation of total dietary intakes, J. Dairy Sci., 91, 4261-4271, doi:10.3168/jds.2008-1093, 2008.

Erickson, P. S., Whitehouse, N. L., and Dunn, M. L.: Activated carbon supplementation of dairy cow diets: Effects on apparent total tract nutrient digestibility and taste preference, The Professional Animal Scientist, 27, 428-434, doi:10.15232/S1080-7446(15)30515-5, 2011.

Galtier, P.: Biological fate of mycotoxins in animals, Rev. Med. Vet., 149, 549-554, 1998.

Garon, D., Richard, E., Sage, L., Bouchart, V., Pottier D., and Lebailly P.: Mycoflora and multimycotoxin detection in maize silage: Experimental study, J. Agric. Food Chem., 54, 34793484, doi:10.1021/jf060179i, 2006.

Hanuš, O., Vyletělová, M., Genčurová, V., Bjelka, M., Kopecký, J., and Jedelská R.: The importance of the raw milk laboratory testing for the dairy farmers, Mliekárstvo, 35, 31-38, 2004 (in Czech).

Hanuš, O., Frelich, J., Janů, L., Macek, A., Zajíčková, I., Genčurová, V., and Jedelská, R.: Impact of different milk yields of cows on milk quality in Bohemian spotted cattle, Acta Vet. Brno, 76, 563-571, doi:10.2754/avb200776040563, 2007.

Hernández-Martínez, R. and Navarro-Blasco, I.: Surveillance of aflatoxin content in dairy cow feedstuff from Navarra (Spain), Anim. Feed Sci. Technol., 200, 35-46, doi:10.1016/j.anifeedsci.2014.12.002, 2015.

Hofstetter, U. and Rodrigues, I.: Evaluation of the effects of rations naturally contaminated with different mycotoxins on Holstein crossbred dairy cows in Southeast Asia and the efficacy of a mycotoxin deactivator, Folia veterinaria, 53, 105-106, 2009.

Charmley, E., Trenholm, H. L., Thompson, B. K., Vudathala, D., Nicholson, J. W. G., Prelusky, D. B., and Charmley L. L.: Influence of level of deoxynivalenol in the diet of dairy cows on feed intake, milk production, and its composition, J. Dairy Sci., 76, 3580-3587, doi:10.3168/jds.S0022-0302(93)77697-3, 1993.

Janů, L., Hanuš, O., Frelich, J., Macek, A., Zajíčková, I., Genčurová, V., and Jedelská R.: Influences of different milk yields of Holstein cows on milk quality indicators in the Czech Republic, Acta Vet. Brno, 76, 553-561, doi:10.2754/avb2O0776040553, 2007.

Jõudu, I., Henno, M., Kaart, T., Püssa, T., and Kärt, O.: The effect of milk protein contents on the rennet coagulation properties of milk from individual dairy cows, Int. Dairy J., 18, 964-967, doi:10.1016/j.idairyj.2008.02.002, 2008.

Kiyothong, K., Rowlinson, P., Wanapat, M., and Khampa, S.: Effect of mycotoxin deactivator product supplementation on dairy cows, Anim. Prod. Sci., 52, 832-841, doi:10.1071/AN11205, 2012.
Korosteleva, S. N., Smith, T. K., and Boermans, H. J.: Effects of feedborne Fusarium mycotoxins on the performance, metabolism, and immunity of dairy cows, J. Dairy Sci., 90, 3867-3873, doi:10.3168/jds.2007-0162, 2007.

Nájera, A. I., de Renobales, M., and Barron, L.: Effects of pH, temperature, $\mathrm{CaCl}_{2}$ and enzyme concentrations on the rennetclotting properties of milk: A multifactorial study, Food Chem., 80, 345-352, doi:10.1016/S0308-8146(02)00270-4, 2003.

Takagi, M., Uno, S., Kokushi, E., Shiga, S., Mukai, S., Kuriyagawa, T., Takagaki, K., Hasunuma, H., Matsumoto, D., Okamoto, K., Shahada, F., Chenga, T., Deguchi, E., and Fink-Gremmels, J.: Measurement of urinary zearalenone concentrations for monitoring natural feed contamination in cattle herds: On-farm trials, J. Anim. Sci., 89, 287-296, doi:10.2527/jas.2010-3306, 2011.

Takagi, M., Shiga, S., Uno, S., Kokushi, E., Otoi, T., Tshering, C., Deguchi, E., and Fink-Gremmels, J.: Periodic alteration in urinary zearalenone excretion in a dairy cattle herd, Anim. Nutr. Feed Techn., 13, 303-310, 2013.

Winkler, J., Kersten, S., Meyer, U., Engelhardt, U., and Dänicke, S.: Residues of zearalenone (ZEN), deoxynivalenol (DON) and their metabolites in plasma of dairy cows fed Fusarium contaminated maize and their relationships to performance parameters, Food Chem. Toxicol., 65, 196-204, doi:10.1016/j.fct.2013.12.020, 2014.

Xiong, J. L., Wang, Y. M., Nennich, T. D., Li, Y., and Liu, J. X.: Transfer of dietary aflatoxin B1 to milk aflatoxin M1 and effect of inclusion of adsorbent in the diet of dairy cows, J. Dairy Sci., 98, 2545-2554, doi:10.3168/jds.2013-7842, 2015.

Yoshizawa, T., Mirocha, C. J., Behrens, J. C., and Swanson, S. P.: Metabolic fate of T-2 toxin in a lactating cow, Food Cosmet Toxicol., 19, 31-39, doi:10.1016/0015-6264(81)90300-X, 1981.

Zachariášová, M., Džuman, Z., Vepříková, Z., Hájková, K., Jírů, M., Václavíková, M., Pospíchalová, M., Florian, M., and Hajšlová, J.: Occurrence of multiple mycotoxins in European feedingstuffs, assessment of dietary intake by farm animals, Anim. Feed Sci. Technol., 193, 124-140, doi:10.1016/j.anifeedsci.2014.02.007, 2014.

Zinedine, A., Soriano, J. M., Molto, J. C., and Manes, J.: Review on the toxicity, occurrence, metabolism, detoxification, regulations and intake of zearalenone: An oestrogenic mycotoxin, Food Chem. Toxicol., 45, 1-18, doi:10.1016/j.fct.2006.07.030, 2007. 